\title{
The opinion of Romanian male tennis players about the importance of mental trainining
}

\section{Simona PETRACOVSCHI모, Sergiu ROGOVEANU²}

\begin{abstract}
The aim of this paper is to analyze the importance of mental preparation for competition in Romanian tennis players. We collected data from 67 Romanian male tennis players (mean age: 24 years) by means of questionnaires. Thus, we applied two questionnaires: a demographic test and SCAT - Sport Competition Anxiety Test. Data were analyzed using SPSS Statistics version 20.0. The results indicate fourth aspects of the analyze: who is in charge with the mental preparation, if the athletes know the modern technics used by the specialists for the mental training for competition, the opinion about necessity of mental training and some aspects of anxiety and the strategies to combat it. The conclusions indicate that the mental preparation under the supervision of a specialist is not high practiced by the Romanian tennis players. The need for a specialist is demanded especially to control the emotions before the competition. The current practice to combat the anxiety is music listening, separation from the group, praying or respiration exercise. There is a largely need to improve this technics.
\end{abstract}

Key words: coach, physical trainer, psycholog, anxiety, coping.

\section{Rezumat}

Scopul acestei cercetări este analiza importanței pregătirii mentale pentru competiție pentru jucătorii de tenis seniori din România. Folosind metoda chestionarului, acesta s-a aplicat la un număr de 67 de jucători de tenis bărbați a căror vârstă medie este de 24 de ani. S-au aplicat două tipuri de chestionar, unul demografic iar cel de-al doilea a fost Testul pentru Verificarea Anxietătii în Competitiile Sportive (SCAT). Analiza statistică a datelor a fost efectuată utilizând programul statistic SPSS, versiunea 20.0. Analiza rezultatelor indica patru aspecte: primul, priveste persoana care se ocupă cu pregătirea mentală a sportivilor, al doilea aspect priveste cunoasterea tehnicilor moderne folosite de către specialisti în pregătirea mentală a sportivilor pentru competitie, urmată de opinia cu privire la necesitatea pregătirii mentale la sportivii si în ultimul rând, unele aspecte cu privire la starea de anxietate si strategiile de combatere ale ei. Concluziile ne indică faptul că pregătirea mentală sub supravegherea unui specialist nu este foarte des practicată de către tenismeni în România. Nevoia de specialist se observă la nivelul controlului emotiilor din-naintea începerii competitiei. Printre practicile curente se observă ascultarea muzicii, izolarea, practicarea rugăciunii sau exercitiile de respiratie. Toate aceste tehnici necesită dezvoltare.

Cuvinte cheie: antrenor, preparator fizic, psiholog, anxietate, strategii.

\footnotetext{
${ }^{1}$ Associate Professor, West University of Timișoara, Faculty of Physical Education and Sport, e-mail: ionescusimo@yahoo.com

2 Master student, West University of Timisoara, Faculty of Physical Education and Sport
} 


\section{Introduction}

The aim of this paper is to analyze the importance of mental preparation for competition in Romanian tennis players.

Known as a professional sport, tennis is high developed in Romania with important results at junior and senior level.

The complete preparation for the competition includes among technical and physical preparation also the mental training. Supported financial only by parents at the beginning, the results of tennis players are important but not sustained by the national federation. In this situation, due to budget limits, not every athlete has included in his program the mental preparation.

Several studies revealed the effects of mental training program on pre-competitive anxiety, selfconfidence and tennis performance in junior tennis players [1]. Moreover, it was assessed the presence of burn-out in competitive junior tennis players [2] or the strategies to build self-efficacy in tennis [3]. In this situation, the need for a mental preparation with a specialist is high demanded and not everyone can help the athlete to resolve the different problems (anxiety, motivation, self-confidence, etc.) In this paper we intend to analyze the situation in Romanian tennis, to see how the players prepare the competition, if there is a support from a psychologist. We also want to find out if the players know the principal technics used by the specialists for the mental preparation.

\section{Material and methods}

We collected data from 67 Romanian male tennis players during three competitions organized in Romania. From the total of 67 players, 23 are ATP classified and the age average is 24 years. We applied two questionnaires: demographic and the SCAT - Sport Competition Anxiety Test [4].

Demographic questionnaire contains 12 items. The questions focused on age, ATP position or nonclassification, mental preparation, psychological technics used.

Sport Competition Anxiety Test contains 15 items, 10 of them measure the symptoms associated with anxiety. The five items that are not scored are designed to reduce the likelihood of an internal response-set bias. The standard instructions of the
SCAT ask respondents to indicate how they "usually feel when competing in sports and games." We replaced the "sports and games with tennis".

On a 3 -point scale ( 1 = hardly ever, 2 = sometimes, 3 = often) respondents indicated the frequency with which they generally experienced the 10 anxiety related symptoms. The scores for the 10 items are summed to provide an overall measure of CTA, with a high composite score (as opposed to a low composite score) reflecting a greater tendency to experience competitive anxiety.

\section{Analysis}

Statistical analysis was performed using the SPSS Statistics version 20.0.

\section{Results}

\section{a. Mental preparation}

As we observed from the table no.1, from the total of 67 male tennis players questioned, only $32.8 \%$ of them are doing the mental preparation with a specialist (psychologist). Generally, the coach is the person who motivates the athlete for the competition with his personal means and knowledge (50.7\%). Also, $7.5 \%$ of the physical trainer are involved in mental preparation of the tennis player and $9 \%$ of them are declaring that they are not mental prepared for the competition by somebody (specialist or non-specialist).

Table I. Who is the mental coach

\begin{tabular}{lcccc} 
& Freq. & Percent & $\begin{array}{c}\text { Valid } \\
\text { Percent }\end{array}$ & $\begin{array}{c}\text { Cumul. } \\
\text { Percent }\end{array}$ \\
\hline Coach & 34 & 50.7 & 50.7 & 50.7 \\
\hline $\begin{array}{l}\text { Physical } \\
\text { trainer }\end{array}$ & 5 & 7.5 & 7.5 & 58.2 \\
\hline Psycholog & 22 & 32.8 & 32.8 & 91 \\
\hline Nobody & 6 & 9.0 & 9.0 & 100.0 \\
\hline Total & 67 & 100.0 & 100.0 & \\
\hline
\end{tabular}

Legend: Freq.= Frequency, Cumul.= Cumulative

\section{b. Types of mental preparation}

They are different types of the mental preparation that the specialists are using in order to prepare the athlete for the competition. These are: autosuggestion, hypnosis, sophrology, NLP (neurolinguistics programming), imagery and behavioral technics or relaxation technics (Jacobson and Schultz). 
As we see in the table no. 2, $55.2 \%$ of athletes surveyed believes that autosuggestion can help largely psychological preparation, $16.4 \%$ think that it helps very much, $25.4 \%$ are not confident in this technique while $1.5 \%$ consider that this technique help them little and very little.

Table II. Tennis players who practice autosuggestion

\begin{tabular}{lcccc}
\hline & Freq. & Percent & $\begin{array}{l}\text { Valid } \\
\text { Percent }\end{array}$ & $\begin{array}{l}\text { Cumul. } \\
\text { Percent }\end{array}$ \\
\hline $\begin{array}{l}\text { Strongly } \\
\text { disagree }\end{array}$ & 1 & 1.5 & 1.5 & 1.5 \\
\hline Disagree & 1 & 1.5 & 1.5 & 3 \\
\hline $\begin{array}{l}\text { Neither agree } \\
\text { or disagree }\end{array}$ & 1.7 & 25.4 & 25.4 & 28.4 \\
\hline Agree & 37 & 55.2 & 55.2 & 83.6 \\
\hline $\begin{array}{l}\text { Strongly } \\
\text { agree }\end{array}$ & 11 & 16.4 & 16.4 & 100.0 \\
\hline Total & 67 & 100.0 & 100.0 & \\
\hline
\end{tabular}

Legend: Freq.= Frequency, Cumul.= Cumulative

In table no. 3 we observed that $47.8 \%$ of athletes surveyed believe that hypnosis can help them in achieving performance in a very small extent, 29.9 $\%$ consider that helps in small extent and $19.4 \%$ are not confident in the technique.

Table III. Tennis players who practice hypnosis

\begin{tabular}{lcccc}
\hline & Freq. & Percent & $\begin{array}{c}\text { Valid } \\
\text { Percent }\end{array}$ & $\begin{array}{c}\text { Cumul. } \\
\text { Percent }\end{array}$ \\
\hline $\begin{array}{l}\text { Strongly } \\
\text { disagree }\end{array}$ & 32 & 47.8 & 47.8 & 47.8 \\
\hline Disagree & 20 & 29.9 & 29.9 & 77.6 \\
\hline $\begin{array}{l}\text { Neither agree } \\
\text { or disagree }\end{array}$ & 13 & 19.4 & 19.4 & 97.0 \\
\hline $\begin{array}{l}\text { Strongly } \\
\text { agree }\end{array}$ & 2 & 3.0 & 3.0 & 100.0 \\
\hline Total & 67 & 100.0 & 100.0 & \\
\hline
\end{tabular}

Legend: Freq.= Frequency, Cumul.= Cumulative

Concerning to sophrology, the athletes do not believe that this technique can help them (40.3\%), $29.9 \%$ consider that only in a very small extent; $20.9 \%$ consider neither disagree or agree, only 7.5 $\%$ are agree and $1.5 \%$ are totally agree (table no 4 ).

Table IV. Tennis players who practice sophrology

\begin{tabular}{lcccc} 
& Freq. & Percent & $\begin{array}{c}\text { Valid } \\
\text { Percent }\end{array}$ & $\begin{array}{c}\text { Cumul. } \\
\text { Percent }\end{array}$ \\
\hline $\begin{array}{l}\text { Strongly } \\
\text { disagree }\end{array}$ & 27 & 40.3 & 40.3 & 40.3 \\
\hline Disagree & 20 & 29.9 & 29.9 & 70.1 \\
\hline $\begin{array}{l}\text { Neither agree } \\
\text { or disagree }\end{array}$ & 14 & 20.9 & 20.9 & 91.0 \\
\hline
\end{tabular}

\begin{tabular}{lrrrr}
\hline Agree & 5 & 7.5 & 7.5 & 98.5 \\
\hline $\begin{array}{l}\text { Strongly } \\
\text { agree }\end{array}$ & 1 & 1.5 & 1.5 & 100.0 \\
\hline Total & 67 & 100.0 & 100.0 & \\
\hline
\end{tabular}

Legend: Freq. $=$ Frequency, Cumul. $=$ Cumulative

$41.8 \%$ of respondents believe that mental imagery helps in getting performance; largely $28.4 \%$ think it helps very much, $14.9 \%$ believe that it helps small extent whereas $11.9 \%$ are not confident in the benefits of this technique (table no. 5).

Table V. Tennis players who practice imagery

\begin{tabular}{lrrrc} 
& Freq. & Percent & $\begin{array}{c}\text { Valid } \\
\text { Percent }\end{array}$ & $\begin{array}{c}\text { Cumul. } \\
\text { Percent }\end{array}$ \\
\hline $\begin{array}{l}\text { Strongly } \\
\text { disagree }\end{array}$ & 2 & 3.0 & 3.0 & 3.0 \\
\hline Disagree & 10 & 14.9 & 14.9 & 17.9 \\
\hline $\begin{array}{l}\text { Neither agree } \\
\text { or disagree }\end{array}$ & 8 & 11.9 & 11.9 & 29.9 \\
\hline Agree & 28 & 41.8 & 41.8 & 71.6 \\
\hline $\begin{array}{l}\text { Strongly } \\
\text { agree }\end{array}$ & 19 & 28.4 & 28.4 & 100.0 \\
\hline Total & 67 & 100.0 & 100.0 & \\
\hline
\end{tabular}

Legend: Freq.= Frequency, Cumul.= Cumulative

Table no. 6 reveals that $35.8 \%$ of athletes believe that neuro - linguistic can help greatly to achieve performance and $31.3 \%$ are very confident in this technique, only $4.5 \%$ recognize its positive effects.

Table VI. Tennis players who practice NLP

\begin{tabular}{lrrrr} 
& Freq. & Percent & $\begin{array}{c}\text { Valid } \\
\text { Percent }\end{array}$ & $\begin{array}{l}\text { Cumul. } \\
\text { Percent }\end{array}$ \\
\hline $\begin{array}{l}\text { Strongly } \\
\text { disagree }\end{array}$ & 5 & 7.5 & 7.5 & 7.5 \\
\hline Disagree & 14 & 20.9 & 20.9 & 28.4 \\
\hline $\begin{array}{l}\text { Neither } \\
\text { agree or } \\
\text { disagree }\end{array}$ & 21 & 31.3 & 31.3 & 59.7 \\
\hline Agree & 24 & 35.8 & 35.8 & 95.5 \\
\hline $\begin{array}{l}\text { Strongly } \\
\text { agree }\end{array}$ & 3 & 4.5 & 4.5 & 100.0 \\
\hline Total & 67 & 100.0 & 100.0 & \\
\hline Legend: Freq & Frequency Cun & & \\
\hline
\end{tabular}

Legend: Freq.= Frequency, Cumul.= Cumulative

Behavioral technics are agreed largely by $43.3 \%$ of tennis players, $11.9 \%$ think that it helps very much; $34.3 \%$ are not confident in the technique while 7.5 $\%$ and $3 \%$ do not believe in the benefits of this technique (table no. 7). 
Table VII. Tennis players who practice behavioral techniques

\begin{tabular}{lccrc} 
& Freq. & Percent & $\begin{array}{c}\text { Valid } \\
\text { Percent }\end{array}$ & $\begin{array}{c}\text { Cumul. } \\
\text { Percent }\end{array}$ \\
\hline $\begin{array}{l}\text { Strongly } \\
\text { disagree }\end{array}$ & 2 & 3.0 & 3.0 & 3.0 \\
\hline Disagree & 5 & 7.5 & 7.5 & 10.4 \\
\hline $\begin{array}{l}\text { Neither } \\
\text { agree or } \\
\text { disagree }\end{array}$ & 23 & 34.3 & 34.3 & 44.8 \\
\hline Agree & 29 & 43.3 & 43.3 & 88.1 \\
\hline $\begin{array}{l}\text { Strongly } \\
\text { agree }\end{array}$ & 8 & 11.9 & 11.9 & 100.0 \\
\hline Total & 67 & 100.0 & 100.0 & \\
\hline
\end{tabular}

Legend: Freq.= Frequency, Cumul.= Cumulative

$71.6 \%$ of respondents believe that the goal setting techniques helps heavily in getting performances, $25.4 \%$ consider that helps greatly while only $3 \%$ are distrustful of this technique (table no.8).

Table VIII. Tennis players who practice goal settings

\begin{tabular}{lcrrr}
\hline & Freq. & Percent & $\begin{array}{c}\text { Valid } \\
\text { Percent }\end{array}$ & $\begin{array}{l}\text { Cumul. } \\
\text { Percent }\end{array}$ \\
\hline $\begin{array}{l}\text { Neither agree } \\
\text { or disagree }\end{array}$ & 2 & 3.0 & 3.0 & 3.0 \\
\hline Agree & 17 & 25.4 & 25.4 & 28.4 \\
\hline Strongly agree & 48 & 71.6 & 71.6 & 100.0 \\
\hline Total & 67 & 100.0 & 100.0 & \\
\hline
\end{tabular}

Legend: Freq. $=$ Frequency, Cumul.= Cumulative

$44.8 \%$ of athletes surveyed are not confident that Jacobson relaxation technique can help in getting performance, $32.8 \%$ think that this technique can help them largely; $6 \%$ see heavily benefits of this relaxation techniques while $10.4 \%$ of them are disagree with this method; $6 \%$ of tennis players are strongly disagree (table no. 9).

Table IX. Tennis players who practice Jacobson

\begin{tabular}{lcrrc}
\hline & Freq. & Percent & $\begin{array}{c}\text { Valid } \\
\text { Percent }\end{array}$ & $\begin{array}{c}\text { Cumul. } \\
\text { Percent }\end{array}$ \\
\hline $\begin{array}{l}\text { Strongly } \\
\text { disagree }\end{array}$ & 4 & 6.0 & 6.0 & 6.0 \\
\hline Disagree & 7 & 10.4 & 10.4 & 16.4 \\
\hline $\begin{array}{l}\text { Neither agree } \\
\text { or disagree }\end{array}$ & 30 & 44.8 & 44.8 & 61.2 \\
\hline Agree & 22 & 32.8 & 32.8 & 94.0 \\
\hline $\begin{array}{l}\text { Strongly } \\
\text { agree }\end{array}$ & 4 & 6.0 & 6.0 & 100.0 \\
\hline Total & 67 & 100.0 & 100.0 & \\
\hline
\end{tabular}

Legend: Freq.= Frequency, Cumul.= Cumulative
$47.8 \%$ of respondents are not confident in the this relaxation technique (Schultz); only $25.4 \%$ consider that helps greatly in getting performance, while $13.4 \%$ and $10.4 \%$ think that there are not or very little help (table no. 10).

Table X. Tennis players who practice Schultz

\begin{tabular}{lccrc}
\hline & Freq. & Percent & $\begin{array}{c}\text { Valid } \\
\text { Percent }\end{array}$ & $\begin{array}{c}\text { Cumul. } \\
\text { Percent }\end{array}$ \\
\hline $\begin{array}{l}\text { Strongly } \\
\text { disagree }\end{array}$ & 7 & 10.4 & 10.4 & 10.4 \\
\hline Disagree & 9 & 13.4 & 13.4 & 23.9 \\
\hline $\begin{array}{l}\text { Neither agree } \\
\text { or disagree }\end{array}$ & 32 & 47.8 & 47.8 & 71.6 \\
\hline Agree & 17 & 25.4 & 25.4 & 97.0 \\
\hline Strongly agree & 2 & 3.0 & 3.0 & 100.0 \\
\hline Total & 67 & 100.0 & 100.0 & \\
\hline Legend: Freq.= Frequency, Cumul.= Cumulative &
\end{tabular}

c. Affirmations about the mental preparation

$95.5 \%$ of respondents considered true the athletes claim that psychological preparation can be understood as an absolutely necessary preparation method of each sport, while a small percentage of $1.5 \%$ believe that psychological preparation is important in preparing athletes (table no.11).

Table XI. The need for mental preparation

\begin{tabular}{lcccc} 
& Freq. & $\begin{array}{c}\text { Perce } \\
\text { nt }\end{array}$ & $\begin{array}{c}\text { Valid } \\
\text { Percent }\end{array}$ & $\begin{array}{c}\text { Cumul. } \\
\text { Percent }\end{array}$ \\
\hline True & 64 & 95.5 & 95.5 & 95.5 \\
\hline False & 1 & 1.5 & 1.5 & 97.0 \\
\hline $\begin{array}{l}\text { I don`t } \\
\text { know }\end{array}$ & 2 & 3.0 & 3.0 & 100.0 \\
\hline Total & 67 & 100.0 & 100.0 & \\
\hline
\end{tabular}

Legend: Freq.= Frequency, Cumul.= Cumulative

$97 \%$ of athletes surveyed consider as true the fact that the psychological preparation can transfer knowledge, skills and attitudes of a person with experience (psychologist) to one with less experience (athlete) while $3 \%$ do not know whether this statement is true or false (table no. 12). 
Table XII. The transfer of knowledge, abilities and attitudes

\begin{tabular}{lrrcr} 
& Freq. & Percent & $\begin{array}{c}\text { Valid } \\
\text { Percent }\end{array}$ & $\begin{array}{l}\text { Cumul. } \\
\text { Percent }\end{array}$ \\
\hline True & 65 & 97.0 & 97.0 & 97.0 \\
\hline $\begin{array}{l}\text { I don`t } \\
\text { know }\end{array}$ & 2 & 3.0 & 3.0 & 100.0 \\
\hline Total & 67 & 100.0 & 100. & \\
\hline
\end{tabular}

Legend: Freq.= Frequency, Cumul.= Cumulative

$91 \%$ of athletes surveyed believe the false claim that only people with mental health problems turn to a psychologist, $3 \%$ believes true this affirmation while $6 \%$ do not know whether it is true or false (table no. 13).

$40.3 \%$ of athletes surveyed believe false statement that psychological preparation is perceived negatively in Romania, $28.4 \%$ think this statement is true while $31.3 \%$ do not know whether psychological preparation is perceived negatively or positively in Romania (table no. 14).

Table XIII. About the psychological problems

\begin{tabular}{lrrrr} 
& Freq. & Percent & $\begin{array}{c}\text { Valid } \\
\text { Percent }\end{array}$ & $\begin{array}{c}\text { Cumul. } \\
\text { Percent }\end{array}$ \\
\hline True & 2 & 3.0 & 3.0 & 3.0 \\
\hline False & 61 & 91.0 & 91.0 & 94.0 \\
\hline I don`t know & 4 & 6.0 & 6.0 & 100.0 \\
\hline Total & 67 & 100.0 & 100.0 & \\
\hline
\end{tabular}

Legend: Freq.= Frequency, Cumul.= Cumulative

Table XIV. Negative perceptions

\begin{tabular}{lcrrr}
\hline & Freq. & Percent & $\begin{array}{c}\text { Valid } \\
\text { Percent }\end{array}$ & $\begin{array}{c}\text { Cumul. } \\
\text { Percent }\end{array}$ \\
\hline True & 19 & 28.4 & 28.4 & 28.4 \\
\hline False & 27 & 40.3 & 40.3 & 68.7 \\
\hline I don`t know & 21 & 31.3 & 31.3 & 100.0 \\
\hline Total & 67 & 100.0 & 100.0 & \\
\hline
\end{tabular}

Legend: Freq.= Frequency, Cumul.= Cumulative

\section{d. Anxiety and competition}

The results of SCAT indicate that $64.2 \%$ of the tennis players has a moderate level of anxiety, 23.9 $\%$ has a low level while $11.9 \%$ of them present a high level of anxiety (table no. 15).
Table XV. SCAT

\begin{tabular}{lcccc}
\hline & Freq. & Percent & $\begin{array}{c}\text { Valid } \\
\text { Percent }\end{array}$ & $\begin{array}{c}\text { Cumul. } \\
\text { Percent }\end{array}$ \\
\hline $\begin{array}{l}\text { Low level of } \\
\text { anxiety }\end{array}$ & 16 & 23.9 & 23.9 & 23.9 \\
\hline $\begin{array}{l}\text { Moderate } \\
\text { level of } \\
\text { anxiety }\end{array}$ & 43 & 64.2 & 64.2 & 88.1 \\
\hline $\begin{array}{l}\text { High level } \\
\text { of anxiety }\end{array}$ & 8 & 11.9 & 11.9 & 100.0 \\
\hline Total & 67 & 100.0 & 100.0 & \\
\hline
\end{tabular}

Legend: Freq.= Frequency, Cumul.= Cumulative

We correlate the SCAT with the age and there are no significant correlations between them (table no. 16) and we can conclude that the problem of anxiety is not linked with the age/experience.

As we can observe in table no. 17, the tennis player believes that a sport psychologist will help them to control the emotions before the competition (47.5\%). Moreover, $16.9 \%$ of the players said that this intervention help them to love competitions and also to better known themselves. A small percent need to learn how to win $(11.9 \%)$ or to lose $(6.8 \%)$.

Table XVI. Correlation Age-SCAT

\begin{tabular}{|c|c|c|c|}
\hline & & Age & SCAT \\
\hline \multirow{3}{*}{ Age } & Pearson Correlation & 1 & -.122 \\
\hline & Sig. (2-tailed) & & .324 \\
\hline & $\mathrm{N}$ & 67 & 67 \\
\hline \multirow{3}{*}{ SCAT } & Pearson Correlation & -.122 & 1 \\
\hline & Sig. (2-tailed) & .324 & \\
\hline & $\mathrm{N}$ & 67 & 67 \\
\hline
\end{tabular}

Table XVII. The need for a specialist

\begin{tabular}{lcrrr} 
& Freq. & Percent & $\begin{array}{r}\text { Valid } \\
\text { Percent }\end{array}$ & $\begin{array}{r}\text { Cumul. } \\
\text { Percent }\end{array}$ \\
\hline $\begin{array}{l}\text { To win } \\
\begin{array}{l}\text { To accept the } \\
\text { defeat }\end{array}\end{array}$ & 7 & 10.4 & 11.9 & 11.9 \\
\hline $\begin{array}{l}\text { To control the } \\
\text { emotions }\end{array}$ & 28 & 41.8 & 47.5 & 66.1 \\
$\begin{array}{l}\text { To like the } \\
\text { competition }\end{array}$ & 10 & 14.9 & 16.9 & 83.1 \\
\hline $\begin{array}{l}\text { Better know } \\
\text { myself }\end{array}$ & 10 & 14.9 & 16.9 & 100.0 \\
\hline \begin{tabular}{l} 
Total \\
\hline $\begin{array}{l}\text { Missing } \\
\text { System }\end{array}$
\end{tabular} & 89 & 88.1 & 100.0 & \\
\hline Total & 67 & 100.0 & & \\
\hline
\end{tabular}


We also were interested to know how the athletes cope with the anxiety before the competition and we find out (table no. 18) that $37.5 \%$ of them are listening music; others (25\%) are praying or staying away from the group (25\%). Some of them (12.5\%) are practicing breathing exercise.

Table XVIII. Cope with anxiety

\begin{tabular}{lcrrr}
\hline & Freq. & Percent & $\begin{array}{c}\text { Valid } \\
\text { Percent }\end{array}$ & $\begin{array}{c}\text { Cumul. } \\
\text { Percent }\end{array}$ \\
\hline Praying & 2 & 3.0 & 25.0 & 25.0 \\
\hline $\begin{array}{l}\text { Separation from } \\
\text { others }\end{array}$ & 2 & 3.0 & 25.0 & 50.0 \\
\hline Listening music & 3 & 4.5 & 37.5 & 87.5 \\
\hline $\begin{array}{l}\text { Respiration } \\
\text { exercises }\end{array}$ & 1 & 1.5 & 12.5 & 100.0 \\
\hline Total & 8 & 11.9 & 100.0 & \\
\hline
\end{tabular}

Legend: Freq.= Frequency, Cumul.= Cumulative

\section{Discussions}

As we can observe from the questions analyzed, the tennis players are not mental prepared for the competition by a specialist. The raison can be the luck of specialist in sport psychology in Romania, the limits of the financial support but sometimes also the mentalities. Generally, the main preparation is limited at technical and physical and is organized by the coach and the physical trainer who accomplish sometimes the role of mental preparation.

The principal techniques used by the specialists in mental preparation are not very known by the tennis players (for example: hypnosis, NLP or sophrology). The common techniques such as autosuggestion, goal settings and imagery are better appreciate by the respondents but not because they are using them, just because they can have an idea about them. The relaxation techniques Schultz and Jacobson are known and used in Romanian sport since the ' 80 but today, even if there are more others technics developed, those seems to be also unknown and less practiced by the tennis players as a consequence of the preparation without specialist in sport psychology.

\section{Conclusions}

We can observe that the mental preparation under the supervision of a specialist is not high practiced by the Romanian tennis players. The need for a specialist is demanded especially to control the emotions before the competition. The current practice to combat the anxiety is music listening, separation from the group, praying or respiration exercise. There is a largely need to improve this techniques.

\section{References}

1. Mamassis G., \& Doganis G. (2004). The effects of a mental training program on juniors pre-competitive anxiety, selfconfidence, and tennis performance, Journal of Applied Sport Psychology, 16(2), 118-137.

2. Gould D., Udry E., Tuffey S., \& Loehr J. (1996). Burnout in competitive junior tennis players: I. A quantitative psychological assessment, Sport Psychologist, 10, 322-340.

3. Weinberg R., Grove R., \& Jackson A. (1992). Strategies for building self-efficacy in tennis players: A comparative analysis of Australian and American coaches, Sport Psychologist, 3-13.

4. Martens R., Vealey R. S., \& Burton D. (1990). Competitive anxiety in sport. Champaign, IL: Human Kinetics. 